\title{
IS THERE A FUTURE FOR THE WORLD COUNCIL OF CHURCHES
}

\section{J. P. OBERHOLZER}

The purpse of this paper is a limited one. It consists of a brief glance through some documents of the W.C.C. with the purpose of considering anew the course of this ecumenical body as it appears from pronouncements of its leaders and from its actions.

As a starting point could serve the report of the General Secretary of the W.C.C., Dr. Philip A. Potter, to the Central Committee in Geneva on August 10, 1976. This was the first full meeting of the Central Committee since the 5th General Assembly of the W.C.C. in Nairobi in November, 1975.

Dr. Potter started with a reference to the Nairobi Assembly. That Assembly, he said, "may have left participants feeling like the ecumenical movement was in the Wilderness. ${ }^{1}$ ) I am not in a position to affirm this statement as a true assessment of the feelings of participants in that Assembly. Leafing through the pages of E.P.S., I find an assortment of statements and resolutions which reflect the usual W.C.C. involvement in politics, the usual onesidedness and bias, the usual reluctance to openly criticise Soviet Russia and the communist powers in general, and the usual ecumenical jargon which we know by now is designed more to cover than to reveal the true motivations of the policy-makers and pace-setters of the W.C.C. It is apparently true that the W.C.C. has run into financial difficulties. A shortfall of Sfr. 1180273 is anticipated for the financial year 1977 and cuts had to be made in the numbers of meetings, administrative expenses and staff. However, in a time of recession financial difficulties cannot be taken as a sign of weakening. To all outward appearances therefore the W.C.C. seems to be alive and well in Geneva.

Yet Dr. Potter deems it necessary to use the simile of the desert as the starting point for what we could call a hortatory sermon to the members of the Central Committee. The really fascinating part of his speech begins with a hermeneutical exercise which offers an interesting insight into the use of Scripture and Theology in the higher echelons of the W.C.C. He starts with a display of typology. There may exist a feeling that the ecumenical movement was in the wilderness, "but for the people of Israel this wilderness period was a very fruitful time. It was there that they entered into a covenant relationship with God, received the Law, and learned the way ahead. Of course they were tested by foes within and without. But they also received the manna or sustaining power of God to go on their pilgrim way." The lines drawn here are very obvious: from the wilderness of the ecumenical movement to

1) E.P.S. 23/43 12th August 1976. 
the wilderness that lay between the land of slavery and the land of promise, from the W.C.C. to Israel, the people of God, from the enemies of the W.C.C. to the enemies of Israel, from the W.C.C.'s need of sustenance and direction to the manna from heaven. In Dr. Potter's mind apparently the issue is very clear. The promised land is waiting. The desert sojourn will be over sooner or later and the ecumenical movement as represented by the W.C.C. will reach its God-given destiny.

This destiny is then formulated in the following statement about the will of God: "God breaks into our varied cultures and histories and wills to create a community which includes all people and cultures under his sovereign will and purpose for the well-being of all." The promised land is a community which includes all people and cultures and which exists for the well-being of all. This theological statement is of course one of the basic tenets of the W.C.C. In the Bangkok Assembly of the C.W.M.E. in 1973 we find mention of "an eschatological community which is committed to man's struggle for liberation, unity, justice, peace and fullness of life. ${ }^{.22}$ ) In its letter to the Churches this assembly declares: "We have also recognised that it is the whole of human reality that he (God) wants to free from all that keeps it in slavery. ${ }^{{ }^{\prime \prime}}$ ) We can also recall here the theme of the Colombo consultation between Hindu, Buddhist, Jewish, Christian and Muslim participants, held under the auspices of the W.C.C.'s Programme on Dialogue. The theme was "Towards World Community". The idea of a comprehensive, universal community is indeed something that pervades ecumenical thinking of over half a century. Nathan Söderblom himself frequently used the phrase "unity of mankind". To him is attributed the statement that "reconciliation and brotherhood amongst the peoples must find a place in the creed no less than other articles of faith"."4) The Stockholm Conference on Life and Work therefore explored the possibilities of "an international order for removing the causes of war.... a better social order..., a just and fraternal social order ...". This again, is echoed by various ecumenical gatherings through the years, and has been expressed very clearly in another way by a special session of the General Assembly of the United Nations in April 1974: "The establishment of a new international economic order based on equity, sovereign equality, interdependence, common interest and co-operation among all States, irrespective of their economic and social systems, which shall correct inequalities and redress existing injustices, make it possible to eliminate the widening gap between the developed and the developing countries, and ensure steadily accelerating economic and social development in

2) Bangkok Assembly 1973, p. 67.

3) Bangkok Assembly 1973, p. 1.

4) The Gospel for all Realms of Life. Reflections on the Universal Christian Conference on Life and Work, Stockholm 1925, W.C.C. 1975, p. 25. 
peace and justice for present and future generations." 5 ) There is a small but significant difference in concept between Dr. Potter's expression of the future order and that of Söderblom. Dr. Potter uses another plural: "a community which includes all people", whereas Söderblom spoke of "brotherhood amongst the peoples". In the time between Stockholm 1925 and Geneva 1976 significant developments took place as to the appraisal of nationalism. One of the social evils identified by the I.M.C. at Tambaram 1938, is nationalism, not so much the self-expressive type of the awakening peoples, but especially the self-satisfied type which reigns in the minds of established peoples and which is of a pharisaic and a concealed self-assertive type, only degrees away from the openly self-assertive type exemplified by fascism. There can indeed be little room for nationalism and the maintenance of national identity within a structure which by its very nature and aims is universal, international and comprehensive. The Working Committee on Church and Society in 1971 classed Nationalism as an ideology with an image of the future: "Nationalism and the search for ethnic and racial separatism are widespread characteristics both of nationstates and of sectors of national population that feel themselves denigrated and oppressed. Critical evaluation centres on two elements: (1) the discrepancy between the size, boundaries and resources of nations or irridentist groups and the increasing interdependence of the world; (2) the barriers that such self-bounded groups interpose between their interests and the interests of the rest of the world. A new vision involves substituting concepts of nationhood, regional co-operation, and cultural pluralism for competition among nations and ethnic groups, and world organisations representing people rather than nations." ${ }^{\circ}$ ) The ecumenical movement, says Dr. Potter, is called "to make real in our time this covenant fellowship of sharing and offering the life of God to 'all the families of the earth'." There is here of course again a direct connection between the covenant given to Israel in the wilderness and the "covenant fellowship" in the W.C.C.

Attention should also be drawn to the phrase "to make real". Apparently this means "to bring into effect". Perhaps the meaning of the phrase "to make real" could be read against the background of what we find in a Church and Society report in 1971: "Christian faith in the presence now and the future coming of Jesus Christ and in the Kingdom of God opens before us the perspective of a new heaven and a new earth - an ultimate good that transcends earthly life. At the same time it dramatises our responsibility for a temporal and earthly future." In the report on Dr. Potter's address

5) Quoted from "Costly Ecumenism", Report of the General Secretary, 1974, in Ecumenical Review, Vol. XXVI, p. 569

6) Op. the Report on "Images of the Future" of the Working Committee on Church and Society, Study Encounter Vol. VII No. 3, 1971, p. 20. 
however, there is no indication that he also spoke about a transcendental reality, a new heaven and a new earth. He is quoted as speaking about "the life of God" and the "sovereign will and purpose" of God, but in view of a community which includes all people and cultures for the well-being of all, a call to make real a covenant fellowship.

His immediate concern, it would appear, is a flaw in this covenant fellowship. "For too long", said Dr. Potter, "there has been a kind of apartheid in relations between the churches and the W.C.C., with occasional and well-defined times of meeting and acting." "There is no future for the ecumenical movement or for the W.C.C. unless there is this inner mutuality between the churches and the Council." The danger inherent in this situation is then illustrated by a reference to the biblical concepts of blessing and curse. "To bless", said Dr. Potter, "means to communicate one's strength, one's self to another, to enable the other to be vigorous and effective." To curse, on the other hand, "means to withdraw one's support from another, to desert the other so that he or she becomes weak, directionless and so loses weight, cracks up, becomes lifeless and is destroyed." He concludes with the pertinent question: "The issue before the churches and the Council is clear will the relationship be one of blessing or of cursing? We cannot be comfortable about the persistent signs of a curse which seems to hang over us."

This then could be the explanation for Dr. Potter's reference to the wilderness in which the ecumenical movement finds itself. The W.C.C. is in danger of becoming weak and directionless, to crack up and be destroyed. The persistent signs of the curse are there.

At least some of the reasons for this wilderness feeling, this consciousness of the signs of a curse, are obvious in the words used by Dr. Potter in his address. What he says about a community which includes all people and cultures under the will and purpose of God for the well-being of all, and what the Church and Society Committee referred to calls "Utopia - the imaginative projection of ideal possibility, thoughtful play with optimal eventualities" 7 ) is nothing less and nothing more than a social order, a projected future which could exist independent of the transcendental Kingdom of God. Utopia is a future that can be realised by development and revolution. In this realisation the methods of the terrorist and the slave camps of Soviet Russia have their part to play. The well-being of all takes on a very sinister meaning when violent death and destruction, exploitation and slavery have become accepied elements in the ecumenical movement's advance towards the future.

7) Study Encounter Vol. VII No. 3, 1971, p. 18. 
We have witnessed the W.C.C.'s programme to combat racism in action, a Moçambique and an Angola where the monetary and moral aid of the W.C.C. helped to establish regimes which apart from being satellites of an atheistic communist power, are more ruthless and crueller than the regimes they replaced. We have buried not only our sons who fell on active duty against terrorists who come to kill with the aid and support of the W.C.C., but also scores of black people, civilians whose only sin was that they did not actively support terrorism.

But let us also turn to the part played by the "classless society", the utopia constructed on the tenets of Marx and Lenin. In September 1973 W.C.C. headquarters received a visit from patriarch Pimen, patriarch of Moscow and all Russia. In his reply to the hearty welcome extended by Dr. Potter the patriarch inter alia expressed his high appreciation of the activities of the Programme to Combat Racism. The most illuminating part of his address however appears in the following quotation from it: "In conclusion I would like to draw your attention to a vital question, that of the need for better mutual understanding and confidence in each other. It is no mere chance for me to put this question. In the course of our ecumenical discussions we, the representatives of the churches from the Soviet Union as well as our brothers from other socialist countries, are rather often coming across misunderstandings of our position by our Western brothers and sometimes their direct distrust in us. That does not surprise us. Such difficulties arise chiefly when we consider social problems, e.g. questions of the relationship between person and society or between the church and the state. We are sure that our opponents are under the influence of propaganda widespread in the West, propaganda which is inimical to our society and which makes it impossible for them to see the unquestionable merits of asocialist mode of life which, as we understand it, corresponds to a large extent to Christian ideals. Our opponents are overlooking the fact that the criteria of a capitalist society cannot be applied to our qualitatively different society. The social evils so typical of the life of many people today just cannot occur within our social structure. We have no rich, no poor. The material level of our $\mathbf{2 5 0}$ million people is high enough and its growth depends exclusively on us, on our conscientious work. We have no privileged and no oppressed. Each citizen has wide and equal rights with all other citizens and our society requires from them - as is quite natural - an honest discharge of their civil duties. That is why, to the question of our western brothers 'Don't you have any defects to be condemned, as we condemn those of our countries?', we reply, 'Yes, we have defects. But these do not cause basic tensions. Our citizens are not alienated from society and society is not alienated from them. We have nothing to con- 
dermn before anybody. We have only to work ourselves to correct our defects and to improve our society.."

Let us repeat that phrase: "We have nothing to condemn before anybody." It was in this same year of the visit of the patriarch to Geneva that Alexander Sozhenitsyn's "Gulag Archipelago" became known in the West. This work has been called "a literary monument to the victims of one of the most monstrous crimes against humanity ever committed." The numbers fed through the sewer system of Soviet Russia's concentration camp system amount to sixty million or more, among them large numbers of believers, members, priests and bishops of the orthodox church, yet the patriarch in Geneva insists: "We have nothing to condemn before anybody." This was more than a year after he received Solzhenitsyn's Lenten letter, which splits open the utter falsehood of the whole situation: "Extinguished are the right to continue the faith of our fathers, and the right of parents to raise their children in their own beliefs, while you, hierarchs of the Church, have made your peace with this and support it, interpreting it as an authentic example of the freedom of religion. You find evidence of religious freedom in the fact that we are forced to turn over our children defenseless - not into neutral hands, but to a domination by atheistic propaganda of the most primitive and unscrupulous kind, as well as in the fact that adolescents torn away from Christianity - (they should under no circumstances get infected by it) - have been left with no room for moral growth except the narrow gap between the handbook of the political agitator and the Criminal Code.

"One half century of the past has already been lost, it is too late to rescue the present, but how can the future of our land be saved?"... "We are losing the last traces and signs of a Christian people. Is it possible that this should not be the main concern of the Russian Patriarch? The Russian Church has its agitated opinion on every injustice in far-away Asia and Africa, but on misfortunes at home - never a word.' ... "The entire governance of the Church, the appointment of priests and bishops (even of disreputable ones, so that the Church might more easily be mocked and destroyed) is conducted as secretly as before by the Council for Religious Affairs. A Church ruled dictatorially by atheists - this is a spectacle unseen in two thousand years. Given over to the atheists' control is also the entirety of the operational management of the Church and the allocation of Church funds - those coppers dropped into the collection by pious hands. Five million roubles at a time are contributed with magnanimous gestures to various extraneous funds, while beggars are chased from the church steps and there is no money to repair a leaking roof in a poor parish. Priests have no

8) Ecumenical Review XXVI, 1974, p. 124. 
authority in their own parishes, only the service itself is still entrusted to them, and that only within the confines of the church; to venture beyond the door to a sick parishioner or to a cemetery requires permission from the town council.

By what reasoning could one convince oneself that the calculated destruction - one directed by atheists - of the body and spirit of the Church is the best method of preserving it? Preservation, but for whom? Certainly not for Christ. Preserved, but by what means? By lies? But after falsehood, with what hands is the Eucharist to be performed?"9)

The big lie exposed by Solzhenitsyn and confirmed by universally known facts, yet ignored by the leaders of the W.C.C., is the real reason for the curse on this ecumenical body. "We have nothing to condemn before anybody." Something in the same vein was reported by E.P.S. from Nairobi. A proposal that the U.S.S.R. be mentioned in connection with the call for respect for human rights and fundamental freedoms in a document on the Helsinki Agreement on disarmament was met by an immediate response from metropolitan Juvenaly of the Russian Orthodox Church. He "said he suddenly felt that he was not in a Christian fellowship... He dit not want the world to have the impression that the W.C.C. is a secular organisation which speaks in this manner... Referring to a letter published in a Nairobi newspaper in which two Russian churchmen claimed cultailment of religious freedom in the U.S.S.R., metropolitan Juvenaly expressed surprise at all the attention this particular letter had received compared with attention given to letters from other sources." ${ }^{10}$ )

The document in question in the end went so far as to include the following sentence: "The General Assembly has devoted a substantial period to the discussion of the alleged denial of religious liberty in the U.S.S.R."11)

There is then a built-in falsehood in the concept of an allencompassing, universal community, a utopia as projected by the W.C.C. Leaving room for atheism and inhumanity on one side, on the other side condemning South Africa and other countries on the basis of caricatures drawn beforehand and then projected on the situation, this new social order, this world community, can be nothing else than a plot of demonic dimensions.

The use made of theology in the propagation of this concept, the free and easy use of Biblical metaphor, the identification of the W.C.C. as institution with the people of God, the categorical statement about the will of God being realised by the machinations of this body, amounts to the sin of blasphemy. God is here called in

9) Quoted from Aleksander Solzhenitsyn, Critical Essays and Documentary Materials.? Ed. John B. Dunlop e.a., 1975, p. $550 \mathrm{ff}$.

10) E.P.S. 37/42 9th December 1975.

11) E.P.S. 38/42 1/th December 1975. 
to stand father for the falsehood and demonisme of a structure formed for double-thinking and double-talk.

This is a situation carrying the germ of death, strangely exemplified by a strained relationship between the W.C.C. and the churches. According to the constitution of the W.C.C. it is a fellowship of churches. If it remained true to its proposed character, a situation would not have developed where in its general secretary decries the relationship between the Council and the churchs as one in which mutuality has become lacking. Yet it is true that from its very beginning the W.C.C. developed in a direction carrying it away from the course of being a fellowship of churches. It became something beside the churches and in many ways independent of the churches. Ecumenical meetings consist only partly of church delegates. Many participants are invited by the leadership of the Council with specific ends in view. Group dynamics and sensitivity training are employed in ecumenical meetings. Thus the Bangkok Assembly of the C.W.M.E. where this technique provided the basis even for the structure of the assembly, found as a major implication: "The insights and experiences of the Conference on Salvation Today cannot be communicated to the churches by documents only. The churches in any given region will have to go through a similar process as the Conference to get the full benefit of what the participants discovered together in Bangkok."12) Fact is that the Programme to Combat Racism has been launched without prior consultation with the churches and in direct conflict with the position on violence taken by the W.C.C. in various gatherings. ${ }^{13}$ ) As the Church and Society Committee stated in 1971: "World organisations should represent people rather than nations. Should not then the World Council represent people rather than churches? That is the dilemma of the W.C.C. in its present situation."

Those of us who are heartened by the prospect of the early demise of the W.C.C., may however still have to wait a long time. It has become a structure with its own momentum and it has proved itself a useful tool in the hands of those striving for a world community, a world government and a world religion. It can surely be no coincidence that the main thrust towards the theology of revolution formulated at the Church and Society Conference in Geneva 1966, came from the Russian Orthodox priest Borovoy. The P.C.R. which eventually appeared in the wake of this conference fits in well with the aims of international communism in Southern Africa.

The outstanding aspect of the present situation is that so many people in South Africa are not able to discern the sinister disregard of justice and equity in the W.C.C. The painful truth is that many of the actions of the W.C.C. against South Africa were initiated

12) Bangkok Assembly 1973, p. 66.

13) Reich Gottes oder Weltgemeinschaft, p. 505. 
and supported by South Africans. Indeed, the polarity becoming visible in the W.C.C. has for a long time been visible in South Africa and the caricatures of the situation mostly wear the stamp "Made in South Africa". The satellites of the W.C.C. in South Africa, especially the Christian Institute and the S.A.C.C., have played their role in the double-talk of the W.C.C. and the bias against South Africa. What was demanded by patriarch Pimen and appartently granted by the W.C.C., "We have only to work ourselves to correct our defects and improve our society", is not granted to us. From the very beginning ecumenical gatherings were fed on horror stories from South Africa. Political and cultural polarities between the Afrikaner and South Africans of British stock were responsible for an intensification of pressure initiated from within South Africa by a powerful press and by personal contact. A picture of the South African scene was formed which has only a remote contact with reality. Everything presented was believed and taken as the basis for the crusade against our country. "Flagrant violation of human rights", "the evil of racial segregation", "extreme crisis" and many more expressions like these became part of ecumenical language on South Africa. No wonder that politically minded black people saw in the ecumenical movement a champion for their aspirations. Black Theology gained immediate acceptance in the ecumenical world as did Pan-Africanism and eventually revolution and terrorism. It is only now that slowly some black people begin to realise that the bullet from the communist weapon in the hands of the terrorist does not carry the label "For white people only", that economic sanction and international action are meant to hit black people too. If the U.S.S.R. could feed millions of its own people into the slave camps, why would black people be exempted from the sacrifice of human lives required for the attainment of an ecumenical world community?

Ecumenism in its good sense, like charity, begins at home. It can only proceed on the basis of a common faith and a common willingness to listen to the word of God in such a way that we hear what God says to us and not what we want God to say.

In our turning away from the ecumenical movement as represented by the W.C.C. (but not only by the W.C.C.), we need not find ourselves in isolation. Isolation from evil is never a bad thing. But we do not have to be isolated from each other, even in a worldwide context, if we remain faithful in our ministerial and theological work, and if the expression of our faith in our daily lives remains true and genuine. The unity of the church of God is given by Him, it is part of the being of the church. There is no substitution for this unity, because it is a unity in the hearts of men, transcending every human border. Yet, this unity vanishes as soon as we try to make a structure of it. Should we deny the existence of peoples and 
identities, the diversity of humanity in many ways, we end up in the desert Dr. Potter spoke of. What God gives, cannot be recreated by man, it can only be received and enjoyed.

When I say that ecumenism should begin at home, I do not have in mind church union of any kind. Nor do I have in mind what the R.E.S. in Cape Town recently called the demonstration of unity by interracial church services. I have in mind the expression of the unity which exists in a genuine way on the whole level of mutual contact between churches and members of churches. I venture to say that it is not the barriers of language, culture and race that are the real devisive factors, but the barriers of selfrighteousness, lovelessness and the thirst for power.

The study of the Bible remains the centre of Christian life. There is no better answer to the dangers of the ungodly powers than devout and sustained study of Holy Scripture. Theology should not be the prerogative of a selected few but should become part of life of the church. The training of pastors should have as basis more study of the languages of the Bible, less sociology and psychology. Biblical Theology should move to the centre of the seminary curriculum. The signs of floundering of the ecumenical movement could to a large extent be attributed to the emergence of a theological thinking which produced a theology of involvement, of development, of revolution, but miserably failed in expressing Biblical Theology.

Resistance against the powers of evil and the uncovering of ulterior motives will remain part of the life of the church. Knowledge of these powers is necessary for effective resistance. In this field the Christian League has a unique position and has rendered a very valuable service, not only to its members but to the whole of our country. It has shown conclusively that the truth remain stronger than the lie. Of course, our emphasis should be positive. Resistance should be the visible side of steadfastness in faith, of the will to reflect in our own lives our obedience to Christ and our joy in his salvation. We need no sensitivity training for this, we have something much more dependable and durable.

May I offer you the prayer of St. Paul for the Ephesians as my prayer for you, for us all:

"For this reason then, I fall on my knees before the Father, from whom every family in heaven and on earth receives its true name. I ask God, from the wealth of his glory, to give you power through his Spirit to be strong in your inner selves, and that Christ will make his home in your hearts, through faith." 